year demonstrator in bacteriology at the Royal Veterinary College before becoming a research officer at the Foot and Mouth Research Station, Pirbright. In 1943 he joined the Biological Department of Imperial Chemical Industries, Ltd., and studied the metabolism and antibacterial action of the sulphonamides and sulphones. This work has led to a better understanding of their application in veterinary medicine, and also to the use of $4: 4^{\prime}$-diamino diphenyl sulphone for the treatment of leprosy; this sulphone is the first effective drug cheap enough to be used on a wide scale. The isolation of the growth-factor for $M y c o$. johnei, first demonstrated by Twort and Ingram in 1913, has added to our knowledge of the acid-fast bacteria and may assist in the development of chemotherapeutic substances. In addition to his main work on the application of chemotherapy to veterinary medicine, Mr. Francis has developed a keen interest in many problems of epizootiology. This has been shown in recent years in his studies of bovine tuberculosis and the relationship of the bovine disease to that in man, on which he published a book in 1947. He was a delegate to the World Health Organization conference in Geneva last year, where recommendations were made for the control of 'zoonoses', or animal diseases transmissible to man.

\section{Scientific Workers and Defence Research in the United States}

A STATEMENT on scientific workers and mobilization, issued on September 12 by the Science Advisory Committee of the United States Office of Defense Mobilization, makes a number of suggestions regarding the participation of universities or academic men of science in research on defence in America. The Department of Defense has already expanded its research and development to more than double that of the late 1940 's, mainly in industry and government laboratories, and only about 10 per cent of it represents work done on contract with universities. The statement expresses the view that the major part of the academic research effort of the United States should, in present circumstances, continue to be devoted to fundamental research, but that there should be an appropriate balance between academic science and the abnormal and immediate demands of military problems. A substantial portion of the academic effort should accordingly be devoted to urgent defence noeds and to building up throughout the academic community a widespread knowledge of the scientific problems of defence and a reserve of scientific workers to meet emergencies.

The statement suggests that outstanding men should be made available to projects which analyse military objectives in a broad area of technology and possible means of achieving them, and also to other defence activities where they can simultaneously learn research needs by participating in them. Specially qualified leaders should be given leave of absence to take positions in the Department of Defense and other government agencies which will familiarize them with the problems needing attention. Universities and colleges, it is suggested, should welcome opportunities for joint projects. To a considerable extent the best place for an individual scientific worker depends on whether his own interest and aptitude are for fundamental research and teaching or for applied research or administrative work on defence projects. Periods of leave for such defence work should be of specified duration, both to prevent undue interruption of an individual's normal activities and to spread participation in defence research. The importance to the United States of research and teaching is a major consideration. With these conditions the Committee believes that research and teaching activities would also benefit by widening the experience of scientific workers. The signatories to the statement include the chairman, Dr. Oliver E. Buckley, and Dr. D. W. Bronk, Dr. L. Dubridge, Dr. J. R. Killian, Dr. R. F. Loeb, Dr. J. B. Conant, Dr. J. R. Oppenheimer, Dr. C. A. Thomas, Dr. A. Waterman, Dr. H. Dryden and Dr. W. Whitman.

\section{French Palæontological Documentation and Trans-} lation Service

The Centre d'Etudes et de Documentation Paléontologiques, Muséum d'Histoire Naturelle, Paris, was set up in 1947 with the aim of providing the palrontological documentation required by the modern research worker in the different branches of the sciences of the earth. In addition to supplying general bibliographical information, the Centre has developed its translation service and provides, for scientific workers in France and elsewhere, French translations of recent publications in other languages, in particular, in Dutch, German, Polish and Russian. It has concentrated on the two types of translation: articles on subjects which are of particular interest at the present time, such as tectonics (and in particular neotectonics), sedimentation, the Quaternary era and evolution; and, within the field of palæontology, translation of works on systematics, especially of those written in Russian, in order that descriptions of new forms should be readily available. So far, nearly four hundred translations have been made, 80 per cent of them being of Russian, Polish or Dutch works. The three-monthly bulletin pub. lished by the Centre gives the titles of the new translations as they are prepared, and complete lists of all the translations made since the Centre was set up can also be obtained. At the request of other organizations or research workers, the Centre also carries out special translations, and these and the diagrams can be easily reproduced. The charges for reproductions of translations are approximately $10 \mathrm{~d}$. per page of text, plus $2 d$. -1 s. each for photostats of the diagrams, depending on the size. Further information can be obtained from J. Roger, Centre d'Etudes et de Documentation Paléontologiques, 3 Place Valhubert, Paris $5^{\mathbf{e}}$.

\section{Preparation of Manuscript for Publication}

UNDER the title "Preparing Technical Material for Publication ; a Manual for Authors of College and Station Publications", the University of Illinois Engineering Experiment Station has issued as Circular Series No. 62 (pp. 39 ; Urbana : University of Illinois, 1951; 60 cents) a revised and enlarged edition of the manual "Preparation of Manuscript" published by the Station fifteen years ago. It deals especially with the publications issued by the Experiment Station and by the College of Engineering, alone or in collaboration with other divisions of the University, including recommendations for the preparation of manuscript and illustrations and also for proof-reading. Much of the material, particularly in the first three chapters relating to the range and form of publications issued by the Station and College, is concermed with the characteristic style or form of those publications; but the succeeding 